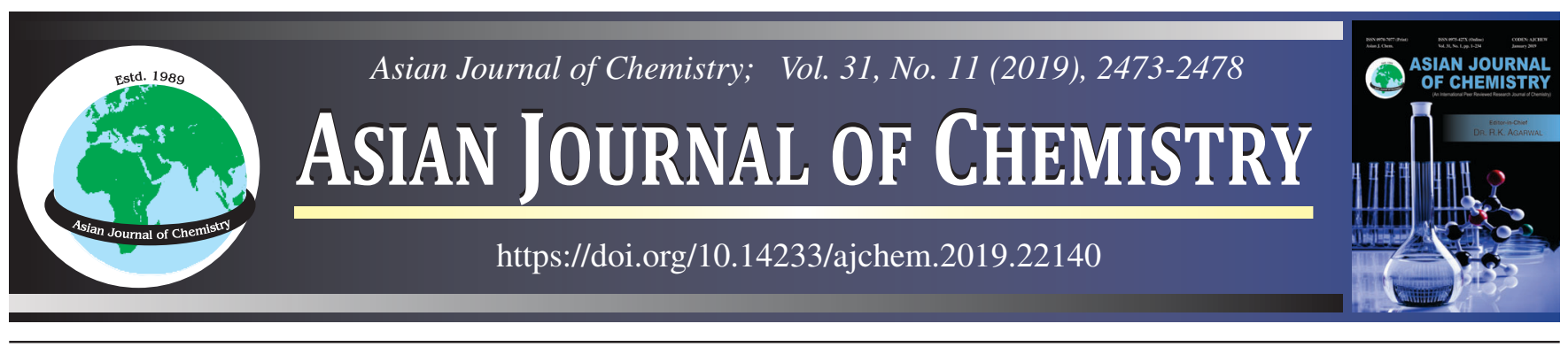

\title{
Quantification of Prochlorperazine and Paracetamol Using High Performance Liquid Chromatography: Application to Tablets and Stability Studies
}

\author{
KADAli JaGADEESH ${ }^{1,2}$ and Nowduri ANNAPURNA,**
}

${ }^{1}$ Department of Basic Science, Shri Vishnu Engineering College for Women, Bhimavaram-534201, India

${ }^{2}$ Department of Engineering Chemistry, AU College of Engineering (A), Andhra University, Visakhapatnam-530003, India

*Corresponding author: E-mail: drannapurna.nowduri@gmail.com

Received: 19 April 2019;

Accepted: 26 May 2019;

Published online: 28 September 2019;

AJC-19572

This study reports a new stability indicating $\mathrm{HPLC}$ method using Spursil $\mathrm{C} 18$ column as stationary phase, and mixture of $0.1 \mathrm{M} \mathrm{Na}_{2} \mathrm{HPO}_{4}$
and methanol (50:50 v/v) as mobile phase for the chromatographic determination of paracetamol and prochlorperazine in tablets and in
bulk form. The linearity range is $250-750 \mu \mathrm{g} / \mathrm{mL}$ for paracetamol and $2.5-7.5 \mu \mathrm{g} / \mathrm{mL}$ for prochlorperazine. The limit of detection values
are $2.650 \mu \mathrm{g} / \mathrm{mL}$ for paracetamol and $0.175 \mu \mathrm{g} / \mathrm{mL}$ for prochlorperazine. The minor values of the relative standard deviation $(\leq 2.0 \%)$ as
well as good percent assay values (nearer to $100 \%$ confirm the high precision and accuracy of the present method. From the degradation
study chromatograms found that there was no interference from degradants when paracetamol and prochlorperazine are quantified in
tablets through the proposed method. A good agreement between results obtained and labeled claim for the determination of paracetamol
and prochlorperazine in tablet samples demonstrates that the proposed method is appropriate to quantify paracetamol and prochlorperazine
in tablet formulations. $\mid$

Keywords: Prochlorperazine, Paracetamol, Migrane, Stability studies.

ᄂ - - - - - - - - - - - - - - - - - - - - - - - - - - - - - -

\section{INTRODUCTION}

Prochlorperazine is an antiemetic and antipsychotic agent belonging to phenothiazines chemical class of drugs [1-4]. Chemically, prochlorperazine is 2-chloro-10-[3-(4-methylpiperazin-1-yl)propyl]phenothiazine (Fig. 1). Prochlorperazine is principally used in nausea and vomiting treatment. This is also used in management of symptomatic psychotic disorders and sufferers with nonpsychotic anxiety. Antiemetic effect is exerted through dopamine blocking inside the chemo-receptor trigger region. Antipsychotic activity is done through blocking D2 somatodendritic autoreceptor and postsynaptic dopamine receptors [5].

Paracetamol, also well-known as acetaminophen, is placed in the acetanilide class of medications. Chemically paracetamol is $N$-(4-hydroxyphenyl)acetamide (Fig. 1). It possesses analgesic as well as antipyretic activity and is prescribed to control fever, headaches and other slight aches and pains [6,7]. Paracetamol is recommended in combination with many other drugs or alone [8]. Paracetamol is believed to act primarily by enhancing the<smiles>CC(=O)Nc1ccc(O)cc1</smiles>

Fig. 1. Chemical structure of chosen drugs

threshold for pain by inhibiting enzymes cyclooxygenase (COX-1, 2 and 3) which are crucial for the prostaglandin synthesis [9]. The antipyretic effect of paracetamol is due to its activity on the hypothalamus thermal management centers [10].

Prochlorperazine and paracetamol combination is used in migraine treatment and management $[11,12]$. This combination treats severe migraine attacks in adults with vomiting and/or nausea. In this combination, paracetamol acts a pain reliever and fever reducer while prochlorperazine acts as anti-nausea medicine. The literature survey suggests that there is no analytical

This is an open access journal, and articles are distributed under the terms of the Attribution 4.0 International (CC BY 4.0) License. This license lets others distribute, remix, tweak, and build upon your work, even commercially, as long as they credit the author for the original creation. You must give appropriate credit, provide a link to the license, and indicate if changes were made. 
procedure, which exists for the quantitative determination of prochlorperazine and paracetamol by using stability indicating HPLC method. For this reason, it was felt essential to develop rapid, selective, specific and sensitive stability indicating liquid chromatographic method for the quantification of prochlorperazine and paracetamol simultaneously. This method was effectively validated by following the International Conference on Harmonization (ICH) rules [13] and also demonstrated its validity by applying the method to assay prochlorperazine and paracetamol simultaneously in available tablet dosage forms.

\section{EXPERIMENTAL}

Prochlorperazine and paracetamol were acquired as gift sample from Rainbow Pharma Training Labs, Hyderabad, India. Neurolice tablets (Alice Healthcare Pvt. Ltd., Chandigarh, India) labeled to have $500 \mathrm{mg}$ paracetamol and $5 \mathrm{mg}$ prochlorperazine were used in this study. Analytical reagent grade hydrogen peroxide, hydrochloric acid, orthophosphoric acid, disodium hydrogen phosphate and sodium hydroxide were acquired from Sd. Fine Chemicals Ltd., Mumbai, India. HPLC grade methanol was acquired from Merck India Ltd, Mumbai, India. Water was purified with Milli-Q water system, Millipore, MA, USA. Membrane filter $(0.45 \mu \mathrm{m})$ was utilized for filtration.

HPLC conditions and instrumentation: Development and validation of method was performed on module 2695 Waters Alliance HPLC system fitted with degasser and column oven. Samples were applied to Spursil, C18 reverse phase column with dimension $250 \mathrm{~mm} \times 4.6 \mathrm{~mm}$, particle size $5 \mu \mathrm{m}$ employing a $10 \mu \mathrm{L}$ autosampler. Efficient separation and estimation of paracetamol and prochlorperazine was achieved with mobile phase mixture $0.1 \mathrm{M} \mathrm{Na}_{2} \mathrm{HPO}_{4}(\mathrm{pH} 4.5)$ :methanol in $50: 50 \mathrm{v} / \mathrm{v}$ ratio at $1.0 \mathrm{~mL} / \mathrm{min}$ flow rate for $6 \mathrm{~min}$ at $25^{\circ} \mathrm{C}$. The eluents were detected and analyzed at a wavelength of $224 \mathrm{~nm}$ using Empower 2 software.

Stock solution of paracetamol and prochlorperazine: Standard stock solution of paracetamol $(5000 \mu \mathrm{g} / \mathrm{mL})$ and prochlorperazine $(50 \mu \mathrm{g} / \mathrm{mL})$ was prepared by dissolving accurately weighed $500 \mathrm{mg}$ (paracetamol) and $5 \mathrm{mg}$ (prochlorperazine) in mobile phase and diluted it to $100 \mathrm{~mL}$ in the volumetric flask.

Calibration: For the calibration graphs, working paracetamol and prochlorperazine solutions of different concentrations $(250,375,500,625$ and $750 \mu \mathrm{g} / \mathrm{mL}$ paracetamol and $2.5,3.75,5.0,6.25$ and $7.5 \mu \mathrm{g} / \mathrm{mL}$ prochlorperazine) were produced by diluting the stock solution. Every solution $(10 \mu \mathrm{L})$ was applied to the HPLC system and the chromatogram was developed under conditions illustrated above. The data obtained was used to plot a graph of drug response (peak area) and quantity of drug.

Method applied to assay paracetamol and prochlorperazine in tablets: The tablet powder containing $500 \mathrm{mg}$ paracetamol and $5 \mathrm{mg}$ prochlorperazine was weighed accurately and transferred to a $100 \mathrm{~mL}$ volumetric flask. The volume was finished with mobile phase to the mark, sonicated for 20 min and after that filtered through $0.45 \mu \mathrm{m}$ membrane filter to obtain $5000 \mu \mathrm{g} / \mathrm{mL}$ paracetamol and $50 \mu \mathrm{g} / \mathrm{mL}$ prochlorperazine. Appropriate volume of filtrate was transferred and diluted with the same solvent in a $10 \mathrm{~mL}$ volumetric flask $(500 \mu \mathrm{g} / \mathrm{mL}$ paracetamol and $5.0 \mu \mathrm{g} / \mathrm{mL}$ prochlorperazine). By applying the suggested method in triplicates, the content of paracetamol and prochlorperazine in tablets was assessed.

Assessment of stability indicating nature: A stability indicating analytical technique precisely measures the drug without interference from potential impurities which were produced during the manufacturing process and storage, and products produced during degradation conditions tested [14]. The test was done by degrading $10 \mathrm{~mL}$ of tablet sample solution (5000 $\mu \mathrm{g} / \mathrm{mL}$ paracetamol and $50 \mu \mathrm{g} / \mathrm{mL}$ prochlorperazine) with $10 \mathrm{~mL}$ of $0.1 \mathrm{~N} \mathrm{HCl}$ (in acidic hydrolysis), $10 \mathrm{~mL}$ of $0.1 \mathrm{~N}$ $\mathrm{NaOH}$ (in base hydrolysis), $10 \mathrm{~mL}$ of water (in neutral hydrolysis), $10 \mathrm{~mL}$ of $30 \%$ hydrogen peroxide (in oxidative degradation) at room temperature with sonication for $30 \mathrm{~min}$. The samples after finishing degradation process were diluted to a final concentration of $500 \mu \mathrm{g} / \mathrm{mL}$ paracetamol and $5 \mu \mathrm{g} / \mathrm{mL}$ prochlorperazine with the mobile phase. For photo and thermal degradation, tablet powder equal to $500 \mathrm{mg}$ paracetamol and $5 \mathrm{mg}$ prochlorperazine was exposed to sunlight for $24 \mathrm{~h}$ (photo degradation) and $105^{\circ} \mathrm{C}$ in a hot air oven (thermal degradation) for $30 \mathrm{~min}$. Following photo and thermal degradation, the sample solution was prepared as described earlier. The method's stability indicating capability was checked by studying the degradation peak interference with peaks of paracetamol and prochlorperazine. The paracetamol and prochlorperazine stability was established by estimating their percentage of degradation under the tested conditions.

\section{RESULTS AND DISCUSSION}

Development of method: The parameters employed for selecting the optimal HPLC conditions were ease of mobile phase preparation, time taken for analyzing one sample, reproducibility of drug's retention time, separation of drug peaks from excipients/degradants, and peak's properties like sharpness, symmetry and resolution.

Five different $\mathrm{C} 18$ columns (Lichrocart: $5 \mu \mathrm{m}$ particle size, $4.6 \times 250 \mathrm{~mm}$; Thermo: $5 \mu \mathrm{m}$ particle size, $4.6 \times 250 \mathrm{~mm}$; Waters: $5 \mu \mathrm{m}$ particle size, $4.6 \times 250 \mathrm{~mm}$; Supleco: $5 \mu \mathrm{m}$ particle size, $4.6 \times 250 \mathrm{~mm}$; Spursil: $5 \mu \mathrm{m}$ particle size, $4.6 \times 250 \mathrm{~mm}$ ) were examined as stationary phases for good separation and quantification of paracetamol and prochlorperazine peaks. The Spursil C18 column $(5 \mu \mathrm{m}$ particle size, $4.6=150 \mathrm{~mm})$ at $25^{\circ} \mathrm{C}$ displayed better separation parameters with a short time period and hence this column was selected for this investigation.

The different mobile phases tested for good separation, peak resolution and sensitivity are: $0.1 \%$ orthophosphoric acid: methanol, $0.1 \mathrm{M} \mathrm{K}_{2} \mathrm{HPO}_{4}$ :methanol and $0.1 \mathrm{M} \mathrm{Na}_{2} \mathrm{HPO}_{4}$ : methanol. All combinations are tested at different organic solvent to aqueous solvent ratios, different $\mathrm{pH}$ and different flow rates. Trials using $0.1 \%$ orthophosphoric acid:methanol and $0.1 \mathrm{M}$ $\mathrm{K}_{2} \mathrm{HPO}_{4}$ :methanol at different combination ratios did not result in good peak separation and these combinations did not provide required peak parameters. After a number of trials, paracetamol and prochlorperazine were optimally separated with the solvent mixture of $0.1 \mathrm{M} \mathrm{Na}_{2} \mathrm{HPO}_{4}$ :methanol at a ratio of $50: 50 \mathrm{v} / \mathrm{v}$, with $\mathrm{pH} 4.5$ and with flow rate of $1.0 \mathrm{~mL} / \mathrm{min}$ in isocratic condition. The same mobile phase solvent mixture was utilized for making all sample solutions. The optimal wavelength for detection and quantification of paracetamol and prochlorperazine was $244 \mathrm{~nm}$. 
Fig. 2 shows the standard paracetamol and prochlorperazine solution chromatograms of under optimum conditions with retention times of $3.030 \mathrm{~min}$ and $4.731 \mathrm{~min}$, respectively for paracetamol and prochlorperazine.

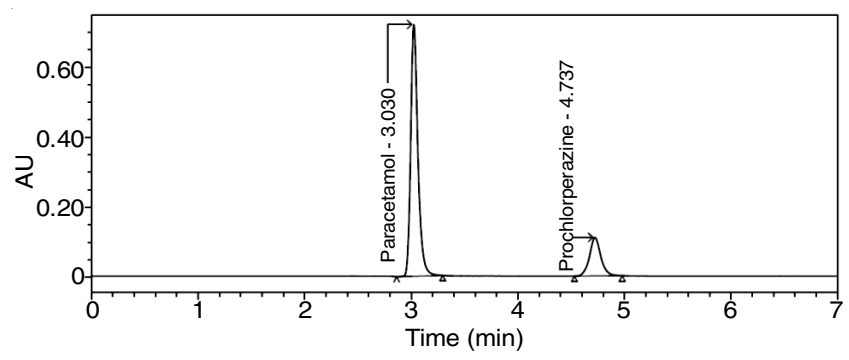

Fig. 2. Standard paracetamol and prochlorperazine chromatogram under optimum conditions with retention time of $3.030 \mathrm{~min}$ (paracetamol) and $4.731 \mathrm{~min}$ (prochlorperazine)

Method validation: The method was validated in compliance with the strategy of International Conference on Harmonization (ICH) [13]. Validation parameters evaluated include linearity, system suitability, accuracy, robustness, precision, specificity, selectivity and sensitivity.

Selectivity: To assess selectivity, the solutions of standard paracetamol $(500 \mu \mathrm{g} / \mathrm{mL})$ and prochlorperazine $(5 \mu \mathrm{g} / \mathrm{mL})$, tablet sample (paracetamol: $500 \mu \mathrm{g} / \mathrm{mL}$ and prochlorperazine: $5 \mu \mathrm{g} / \mathrm{mL}$ ), placebo and mobile phase were injected into the HPLC system. The respective chromatograms obtained were analyzed.
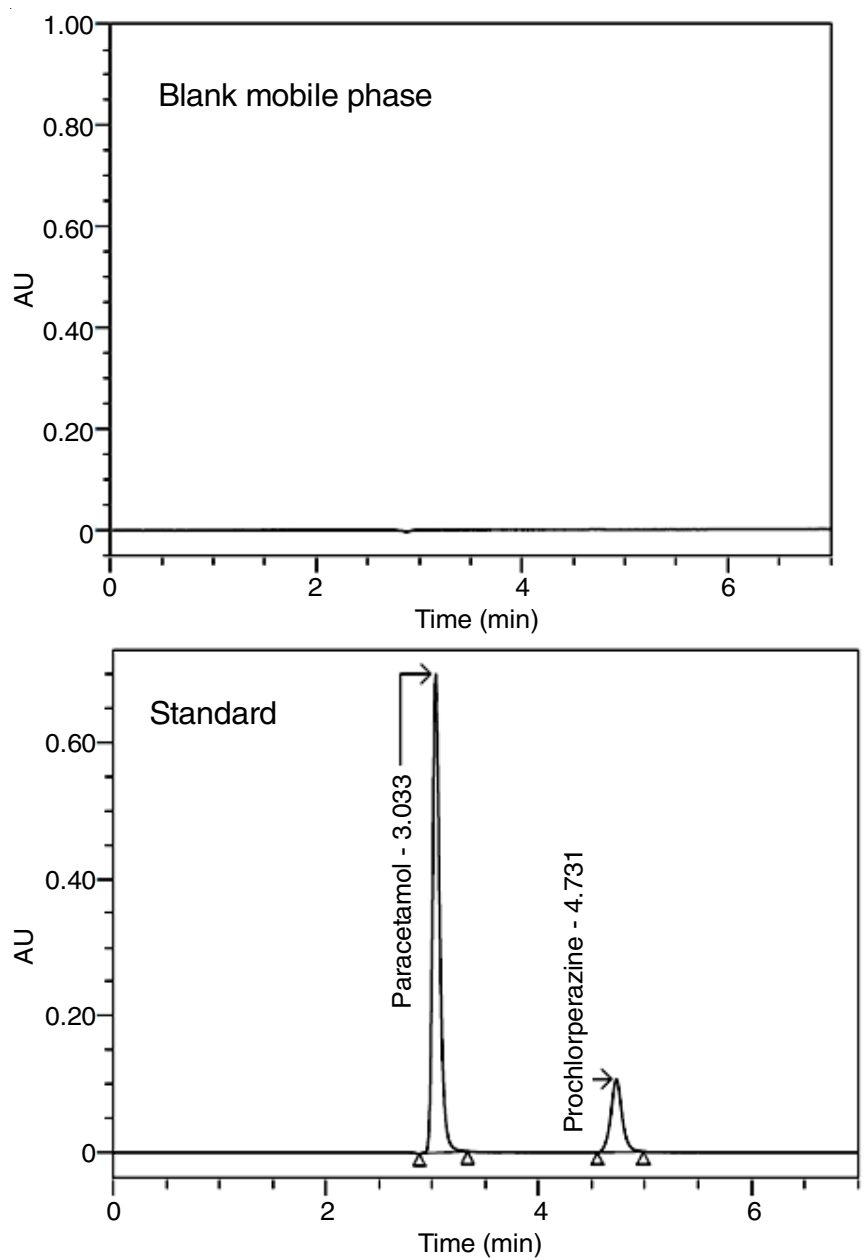

No interfering peaks were observed in chromatograms of mobile phase, placebo and tablet sample at the paracetamol and prochlorperazine peak retention times. This test's chromatograms are shown in Fig. 3. These findings showed selectivity of the method.

System suitability: The suitability of the system was checked to assure that the system functioning and consequences were met the technical requirements. The working solution was injected 6 times. The several features were checked viz. (a) relative standard deviation for retention times of paracetamol and prochlorperazine; (b) relative standard deviation for peak areas of paracetamol and prochlorperazine; (c) resolution for of paracetamol and prochlorperazine peaks; (d) plate count that shows the column efficiency; and (e) tailing or asymmetry factor that shows the peak shape.

The system is best suited for prochlorperazine and paracetamol analyses since the results are within the approval criterion (Table-1).

Linearity: Paracetamol and prochlorperazine calibration plots were made by counter-concentration plotting peak area. A linear regression coefficient of $>0.999$ was found in the range of $250-750 \mu \mathrm{g} / \mathrm{mL}$ for paracetamol and $2.5-7.5 \mu \mathrm{g} / \mathrm{mL}$ for prochlorperazine. Linear regression equations were $\mathrm{y}=6521 x$ $+1298\left(\mathrm{R}^{2}=0.9994\right)$ for paracetamol; and $\mathrm{y}=15641 x-556.5$ $\left(\mathrm{R}^{2}=0.9992\right)$ for prochlorperazine.

Limit of quantitation and limit of detection: Limit of quantitation and limit of detection were evaluated by diluting known concentration of standard paracetamol and prochlor-
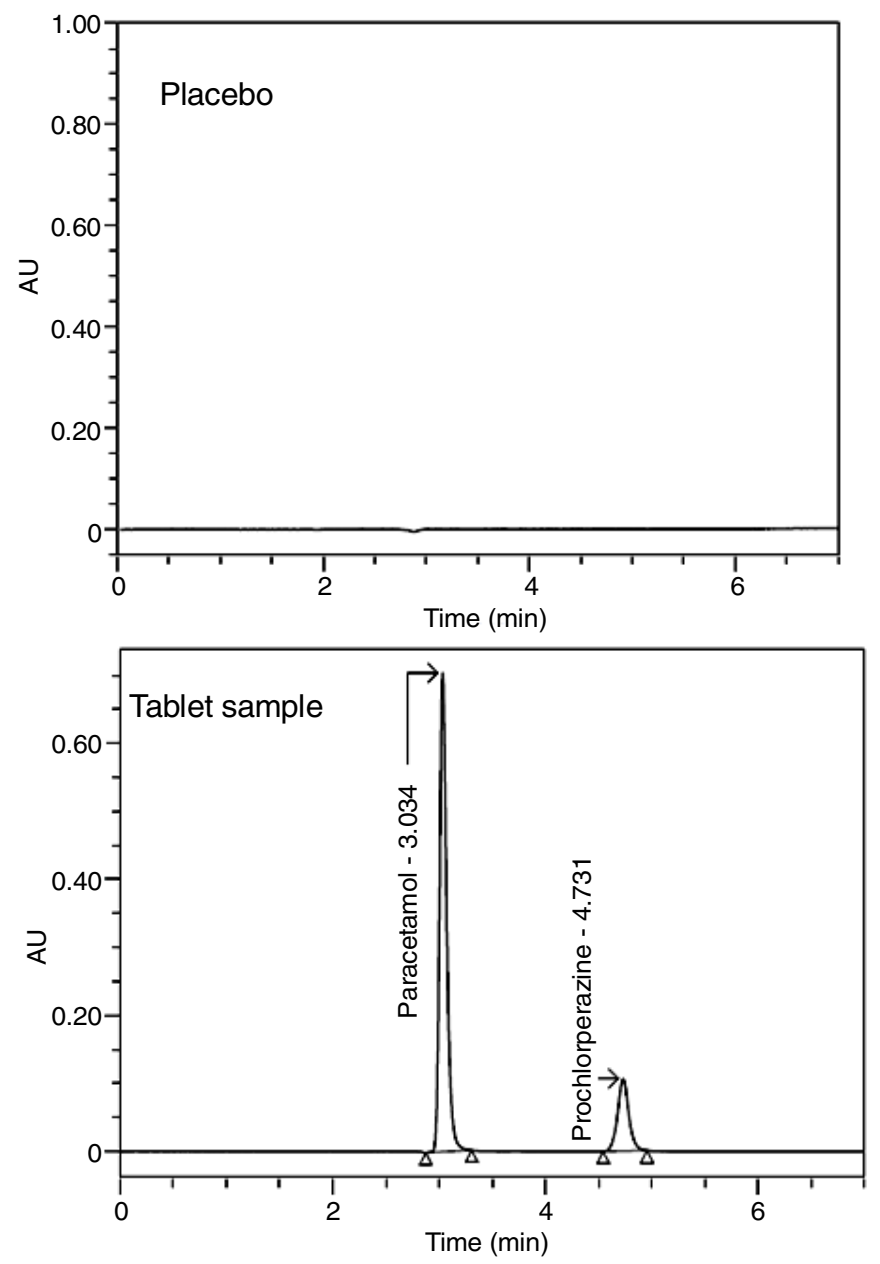

Fig. 3. Chromatograms proving selectivity 


\begin{tabular}{|c|c|c|c|}
\hline \multicolumn{4}{|c|}{$\begin{array}{c}\text { TABLE-1 } \\
\text { SYSTEM SUITABLENESS DATA FOR ASSAY OF } \\
\text { PARACETAMOL AND PROCHLORPERAZINE }\end{array}$} \\
\hline Parameter & Drug & Value* & $\begin{array}{c}\text { Recommended } \\
\text { value }\end{array}$ \\
\hline $\begin{array}{l}\text { Peak area, } \\
\text { RSD }\end{array}$ & $\begin{array}{l}\text { Paracetamol } \\
\text { Prochlorperazine }\end{array}$ & $\begin{array}{c}3261104,0.108 \\
780048,0.681\end{array}$ & $\begin{array}{l}\text { RSD should not } \\
\text { exceed } 2.0 \%\end{array}$ \\
\hline $\begin{array}{l}\text { Retention } \\
\text { time, RSD }\end{array}$ & $\begin{array}{l}\text { Paracetamol } \\
\text { Prochlorperazine }\end{array}$ & $\begin{array}{l}3.032,0.049 \\
4.731,0.035 \\
\end{array}$ & $\begin{array}{l}\text { RSD should not } \\
\text { exceed } 2.0 \%\end{array}$ \\
\hline Plate count & $\begin{array}{l}\text { Paracetamol } \\
\text { Prochlorperazine }\end{array}$ & $\begin{array}{l}10472 \\
10314 \\
\end{array}$ & $\begin{array}{l}\text { Should exceed } \\
2000 \text { counts }\end{array}$ \\
\hline $\begin{array}{l}\text { Peak } \\
\text { tailing }\end{array}$ & $\begin{array}{l}\text { Paracetamol } \\
\text { Prochlorperazine }\end{array}$ & $\begin{array}{l}1.288 \\
1.064 \\
\end{array}$ & $\begin{array}{l}\text { Should not } \\
\text { exceed } 2.0\end{array}$ \\
\hline Resolution & $\begin{array}{l}\text { Paracetamol } \\
\text { Prochlorperazine }\end{array}$ & $\begin{array}{c}- \\
10.714\end{array}$ & $\begin{array}{l}\text { Should exceed } \\
1.5\end{array}$ \\
\hline
\end{tabular}

*Average of five values

perazine stock solution until the mean responses were about ten or three times the responses shown by the blank. Detection limits were $2.650 \mu \mathrm{g} / \mathrm{mL}$ and $0.175 \mu \mathrm{g} / \mathrm{mL}$ and quantitation limits were $8.832 \mu \mathrm{g} / \mathrm{mL}$ and $0.584 \mu \mathrm{g} / \mathrm{mL}$ for paracetamol and prochlorperazine, respectively. The values proved adequate sensitivity of the method.

Precision: Standard paracetamol $(500 \mu \mathrm{g} / \mathrm{mL})$ and prochlorperazine $(5 \mu \mathrm{g} / \mathrm{mL})$ solutions have been prepared. The solution has been injected 6 times into the system. Paracetamol and prochlorperazine peak areas and their relative standard deviations percent (Table-2) were determined. The method was considered to be precise, because the relative standard deviation percentage dropped within the approval criterion $(\leq 2 \%)$.

Accuracy: The recovery analyses were actually performed to verify the accuracy of the method. The preanalyzed tablet sample solution was spiked with paracetamol $(250,500,750$ $\mu \mathrm{g} / \mathrm{mL})$ and prochlorperazine $(2.5,5.0,7.5 \mu \mathrm{g} / \mathrm{mL})$ concentrations corresponding to 50,100 and $150 \%$ levels.

Analytical results at 50,100 and $150 \%$ of spiked samples are shown in Table-2. Within the acceptance criteria of 85-
$115 \%$, paracetamol and prochlorperazine recovery was observed. This showed that the method has sufficient capacity for the definite evaluation of paracetamol and prochlorperazine in formulation samples.

Specificity and degradation study: The motive of this stability indicating check was to show whether the peaks of degradants formed in the course of applied situations were resolved from the peaks of paracetamol and prochlorperazine. The degraded products were well resolved from the paracetamol and prochlorperazine with significantly different retention time values (Fig. 4). The degradation of paracetamol was observed most in acid condition and minimal in neutral condition. For prochlorperazine, it was observed most in oxidative condition with hydrogen peroxide and minimal in neutral condition. The final results of forced degradation test are shown in Table-3. Method's specificity for paracetamol and prochlorperazine was weighed by photodiode array detector through comparing peak threshold value with peak purity angle. Greater the threshold value from purity angle value in the presence of degradation products confirms the selectivity of method for paracetamol and prochlorperazine (Table-3).

Robustness: The robustness is the method's capacity to stay unaffected by little purposeful changes in chromatographic basic parameters. To decide the robustness of the present technique, $\mathrm{pH}$ of buffer, ratio of organic phase in mobile phase, column temperature, flow rate and detection wavelength were changed and values of system suitability features of these changed conditions were measured. The observed outcomes are shown in Table-4 and indicate the method's robustness.

Quantification of paracetamol and prochlorperazine in tablets: Appropriately diluted solutions $(10 \mu \mathrm{L})$ of test tablet samples (concentration $500 \mu \mathrm{g} / \mathrm{mL}$ paracetamol and $5 \mu \mathrm{g} / \mathrm{mL}$ prochlorperazine) were applied thrice into the HPLC system. The chromatogram was developed using determined conditions as described above and was detected at $244 \mathrm{~nm}$. Peak areas of

TABLE-2

PRECISION AND ACCURACY OF PARACETAMOL AND PROCHLORPERAZINE BY THE METHOD

\begin{tabular}{clcc}
\hline Validation parameter & \multicolumn{1}{c}{ Testing parameter } & Paracetamol & Prochlorperazine \\
\hline Precision (values in precision test & Peak area & 3264028 & 781148 \\
are average of six values) & RSD & 0.778 & 0.559 \\
\hline \multirow{2}{*}{ Accuracy (values in accuracy test } & Recovery percent at 50 \% spiked level & 99.88 & 99.74 \\
are average of three values) & Recovery percent at 100 \% spiked level & 100.02 & 99.67 \\
& Recovery percent at 150\% spiked level & 100.02 & 99.90 \\
\hline
\end{tabular}

TABLE-3

FINDINGS OF DEGRADATION STUDY

\begin{tabular}{|c|c|c|c|c|c|}
\hline Condition & Drug & Stability (\%) & Degradation $(\%)$ & Purity angle & Threshold value \\
\hline \multirow{2}{*}{ Acid } & Paracetamol & 90.56 & 9.44 & 0.359 & 0.509 \\
\hline & Prochlorperazine & 98.75 & 1.25 & 0.254 & 0.566 \\
\hline \multirow{2}{*}{ Base } & Paracetamol & 91.25 & 8.75 & 0.233 & 0.507 \\
\hline & Prochlorperazine & 98.15 & 1.85 & 0.336 & 0.654 \\
\hline \multirow{2}{*}{ Neutral } & Paracetamol & 99.45 & 0.55 & 0.370 & 0.506 \\
\hline & Prochlorperazine & 99.15 & 0.85 & 0.294 & 0.658 \\
\hline \multirow{2}{*}{ Hydrogen peroxide } & Paracetamol & 92.85 & 7.15 & 0.298 & 0.504 \\
\hline & Prochlorperazine & 90.55 & 9.45 & 0.239 & 0.657 \\
\hline \multirow{2}{*}{ Thermal } & Paracetamol & 98.55 & 1.45 & 0.259 & 0.606 \\
\hline & Prochlorperazine & 98.44 & 1.56 & 0.244 & 0.755 \\
\hline \multirow{2}{*}{ Sunlight } & Paracetamol & 98.15 & 1.85 & 0.304 & 0.612 \\
\hline & Prochlorperazine & 99.05 & 0.95 & 0.255 & 0.592 \\
\hline
\end{tabular}



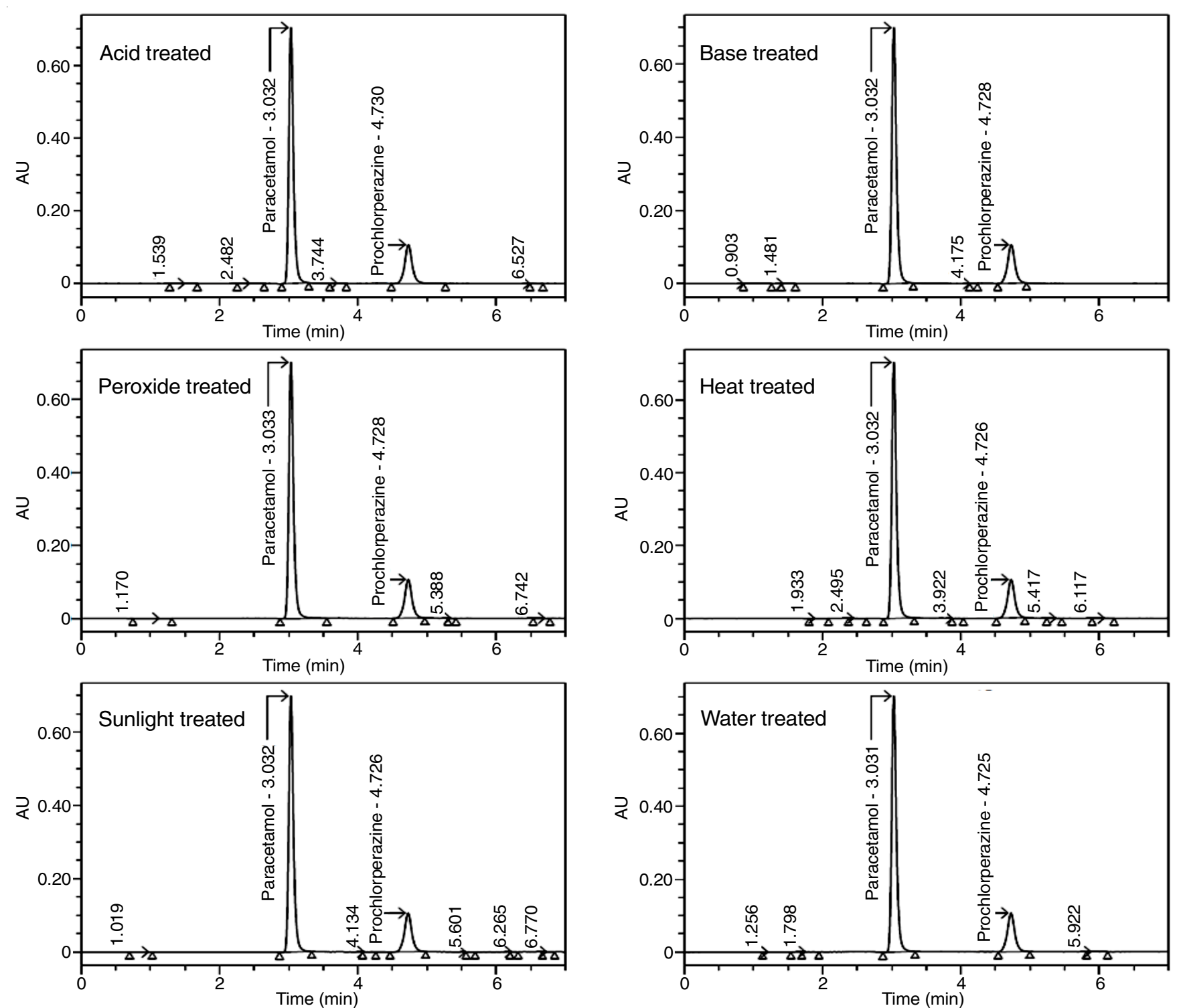

Fig. 4. Chromatograms of degraded samples

\begin{tabular}{|c|c|c|c|c|c|}
\hline \multicolumn{6}{|c|}{$\begin{array}{c}\text { TABLE-4 } \\
\text { ROBUSTNESS DATA FOR PARACETAMOL AND PROCHLORPERAZINE }\end{array}$} \\
\hline Parameter & Drug & Condition & Plate count & Tailing factor & Resolution \\
\hline \multirow{4}{*}{$\begin{array}{l}\text { Change in mobile phase } \\
\text { ratio }\end{array}$} & \multirow{2}{*}{ Paracetamol } & $45: 55 \mathrm{vol} / \mathrm{vol}$ & 6167 & 1.13 & - \\
\hline & & $55: 45 \mathrm{vol} / \mathrm{vol}$ & 9013 & 1.16 & - \\
\hline & \multirow{2}{*}{ Prochlorperazine } & $45: 55 \mathrm{vol} / \mathrm{vol}$ & 5338 & 0.92 & 7.31 \\
\hline & & $55: 45 \mathrm{vol} / \mathrm{vol}$ & 7493 & 0.94 & 8.99 \\
\hline \multirow{4}{*}{ Change in $\mathrm{pH}$} & \multirow{2}{*}{ Paracetamol } & 4.3 units & 10570 & 1.28 & - \\
\hline & & 4.7 units & 10364 & 1.28 & - \\
\hline & \multirow{2}{*}{ Prochlorperazine } & 4.3 units & 10129 & 1.05 & 10.69 \\
\hline & & 4.7 units & 10001 & 1.02 & 10.56 \\
\hline \multirow{4}{*}{ Change in flow rate } & \multirow{2}{*}{ Paracetamol } & $0.9 \mathrm{~mL} / \mathrm{min}$ & 6167 & 1.13 & - \\
\hline & & $1.1 \mathrm{~mL} / \mathrm{min}$ & 6700 & 1.13 & - \\
\hline & \multirow{2}{*}{ Prochlorperazine } & $0.9 \mathrm{~mL} / \mathrm{min}$ & 5338 & 0.92 & 7.31 \\
\hline & & $1.1 \mathrm{~mL} / \mathrm{min}$ & 5037 & 0.92 & 7.54 \\
\hline \multirow{4}{*}{$\begin{array}{l}\text { Change in column } \\
\text { temperature }\end{array}$} & \multirow{2}{*}{ Paracetamol } & $23^{\circ} \mathrm{C}$ & 9013 & 1.16 & - \\
\hline & & $27^{\circ} \mathrm{C}$ & 11063 & 1.22 & - \\
\hline & \multirow{2}{*}{ Prochlorperazine } & $23^{\circ} \mathrm{C}$ & 7493 & 0.94 & 8.99 \\
\hline & & $27^{\circ} \mathrm{C}$ & 9844 & 0.98 & 10.48 \\
\hline \multirow{4}{*}{$\begin{array}{l}\text { Change in wavelength } \\
\text { for detection }\end{array}$} & \multirow{2}{*}{ Paracetamol } & $242 \mathrm{~nm}$ & 10708 & 1.31 & - \\
\hline & & $246 \mathrm{~nm}$ & 10608 & 1.30 & - \\
\hline & \multirow{2}{*}{ Prochlorperazine } & $242 \mathrm{~nm}$ & 10649 & 1.08 & 10.96 \\
\hline & & $246 \mathrm{~nm}$ & 10376 & 1.11 & 10.78 \\
\hline
\end{tabular}


paracetamol and prochlorperazine were recorded and used the respective calibration plot or regression equation to analyze paracetamol and prochlorperazine contents present in tablet samples (Table-5). The content assay and RSD values obtained proved accurateness and preciseness of the method to assay paracetamol and prochlorperazine in tablets.

\begin{tabular}{ll}
\multicolumn{1}{c}{ TABLE-5 } \\
\multicolumn{1}{c}{ ASSAY OF PARACETAMOL AND } \\
PROCHLORPERAZINE IN TABLET
\end{tabular}

\section{Conclusion}

In this work, stability indicating HPLC method provide a rapid, selective, specific, accurate and precise way for quantifiable analysis of paracetamol and prochlorperazine in its pure and tablet dosage form. As the method ought to efficiently separate paracetamol and prochlorperazine from their degradation products, it can be utilized as stability indicating technique. The recommended method found is sensitive and can be employed regularly in quality control labs and in degradation studies for the analysis of paracetamol and prochlorperazine.

\section{CONFLICT OF INTEREST}

The authors declare that there is no conflict of interests regarding the publication of this article.

\section{REFERENCES}

1. C. Hempel, W. Nörenberg, H. Sobottka, N. Urban, A. Nicke, W. Fischer and M. Schaefer, Neuropharmacol, 75, 365 (2013); https://doi.org/10.1016/j.neuropharm.2013.07.027.

2. M.L.M. Lin, P.D. Robinson, J. Flank, L. Sung and L.L. Dupuis, Drug Saf., 39, 509 (2016); https://doi.org/10.1007/s40264-016-0398-9.

3. D.H. Cunningham, G.J. Forrest, M. Soukop, N.L. Gilchrist, I.T. Calder and C.S. Mcardle, Br. Med. J., 291, 864 (1985); https://doi.org/10.1136/bmj.291.6499.864.

4. A.E. Patanwala, R. Amini, D.P. Hays and P. Rosen, J. Emerg. Med., 39, 330 (2010); https://doi.org/10.1016/j.jemermed.2009.08.060.

5. H.S. Smith, L.R. Cox and B.R. Smith, Ann. Palliat. Med., 1, 137 (2012); https://doi.org/10.3978/j.issn.2224-5820.2012.07.09.

6. E.J. Giamarellos-Bourboulis, A. Spyridaki, A. Savva, M. Georgitsi, T. Tsaganos, M. Mouktaroudi, M. Raftogiannis, A. Antonopoulou, V. Papaziogas, F. Baziaka, K. Sereti, P. Christopoulos, A. Marioli, T. Kanni, P. Maravitsa, I. Pantelidou, K. Leventogiannis, P. Tsiaoussis, K. Lymberopoulou and I.M. Koutelidakis, J. Pharmacol. Sci., 124, 144 (2014); https://doi.org/10.1254/jphs.13133FP.

7. C.A. Pierce and B. Voss, Ann. Pharmacother, 44, 489 (2010); https://doi.org/10.1345/aph.1M332.

8. A. Gatti, E. Sabato, A.R. Di Paolo, M. Mammucari and A.F. Sabato. Clin. Drug. Investig., 30 Supl 2, 3 (2010).

9. B. Hinz and K. Brune, Ann. Rheum. Dis., 71, 20 (2012); https://doi.org/10.1136/ard.2011.200087.

10. D.M. Aronoff and E.G. Neilson, Am. J. Med., 111, 304 (2001). https://doi.org/10.1016/S0002-9343(01)00834-8.

11. F. Antonaci, N. Ghiotto, S. Wu, E. Pucci and A. Costa, SpringerPlus, 5, Article No. 637 (2016); https://doi.org/10.1186/s40064-016-2211-8.

12. J.J.Y. Ong and M. De Felice, Neurotherapeutics, 15, 274 (2018); https://doi.org/10.1007/s13311-017-0592-1.

13. International Conference on Harmonization; Validation of Analytical Procedures: Text and Methodology, Q2 (R1), IFPMA, Geneva, Switzerland (2005).

14. International Conference on Harmonization (ICH) of Technical Requirements for the Registration of Pharmaceutical for Human Use Stability Testing of New Drugs Substance and Products Q1A (R2), Geneva, Switzerland (2003). 